\title{
Deep-Sea Mining Law in Indonesia: Challenges and Opportunities
}

\author{
Dhiana Puspitawati \\ International Law Department \\ Faculty of Law \\ Brawijaya University \\ Malang, Indonesia \\ dhiana@ub.ac.id
}

\begin{abstract}
This paper provides a preliminary review in regards to the challenges and opportunities of legal frameworks establishment for the deep-sea mining in Indonesia. While it is relatively new, deep-sea mining has become a very essential issue in international forum. In an effort to become independent of imports and safeguard themselves from future supply shortage, some countries are contemplating mining of resources from the ocean. Indonesia, statistically wise is the number six of big potential resources in the world. Despite the enormous growth of mining in Indonesia, such a deep-sea mining was never done before. In fact, potential opportunities through deep-sea mining activities can be achieved through regional cooperation, by supporting the participation and providing opportunities for qualified scientists and technical personnel in marine scientific research program and activities. However, from Indonesian perspective deep-sea mining is still too expensive and there is uncertainty about its environmental impact. The lack of legal framework concerning deep-sea mining has added more challenges for Indonesia. Thus, it is essential for the Indonesian government to have sufficient legal framework which confirm customary international laws as well as existing international legal framework in deep-sea mining. It is submitted that despite the opportunities that Indonesia has, the lack of legal framework concerning ocean mining is unfortunate. Thus, establishment of sufficient legal framework in respect to the deep-sea mining is crucial.
\end{abstract}

Keywords- Deep-sea mining, Indonesia, challenges, opportunities, seabed, legal framework.

\section{INTRODUCTION}

Natural resources often relates to a nation's economic growth. However, to make use of natural resources, human resources capacity also plays a vital role. It is argued that if a state has high natural resources and high quality as well as capacity on human resources, such a state is regarded as a developed state. ${ }^{1}$ While many have been sceptic about the various implications resulting from land-resources mining, the decreasing availability of land-resources has made state begin looking at the possibility of ocean mining. It is argued that ocean is the largest earth surface over which numerous natural resources, both living and non-living resources, can be found. Natural resources in this paper are referred to nonliving resources or in other word, ocean mineral. Ocean mineral can be defined as "mineral nutrient (chemical element) extracted from deep ocean water found at ocean

\footnotetext{
Such as Canada, NewZealand, Australia and Norway.
}

depths of between 250 and 1500 metres [1]." Furthermore, with regard to ocean water, there are in fact three layers of ocean water, which include surface sea water, deep ocean water and very deep ocean water. The sea water surface is the layer over which sunlight penetration is circulated rapidly along with the change of seasons and winds. This layer supports micro and animal life up to 250 metres in depth. Deep ocean water is present at the depth of 250 until 1500 metres. In this layer, ocean mineral can be found. Whereas, very deep ocean water ranges from 1500 metres to 15 kilometres in depth over which more mineral nutrients can be found. It follows from the above that the exploration and exploitation of such resources need further advanced marine technology as well as sufficient legal frameworks, which accommodate the interests of those who own the technology and those owning the territory, to come to a balanced arrangement.

Along with the possibility of ocean mining, in fact, international society has agreed on international convention, which regulates a comprehensive use of the ocean.[2] ${ }^{2}$ The longest and largest united nation conference in history has taken place for almost 25 years [3], which has negotiated more that three hundred articles of a treaty covering almost every aspect of the use of ocean space. Such efforts made by United Nations ended up with the adoption of the Law of the Sea Convention 1982 (LOSC) [4]. Part XI of LOSC specifically regulates area and considers the legal regime of area as 'common heritage of mankind'. While as stated before that ocean minerals can be found in various depths of sea waters (vertically divide ocean waters into three layers), the contour of ocean floor also varies between states. In addition, LOSC adopted the system of maritime zones, which determine the spatial competence and jurisdiction of States, and this way divides ocean waters horizontally into various maritime zones. Consequently, deep sea mineral deposit occurs in various maritime zones, over which states' competence and juris diction also vary. Thus, in examining the legal framework which regulates deep-sea mining it is necessary to distinguish between the legal frameworks that regulate deep-sea mining under national jurisdiction and those which regulate deep-sea mining beyond national

\footnotetext{
Although LOSC encompasses legal arrangement for a comprehensive use of the ocean space, the use of ocean space as means of transportation is excluded from the provisions of LOSC. Further regulation on the use of ocean as the means of transportation is produced under the auspice of International Maritime Organization (IMO).
} 
juris diction [5]. For the purpose of this study, the discussion focuses on the mining on the seabed at a depth of 250 metres or more so as to clearly separate mining from the extraction of aggregates [6]. ${ }^{3}$

This paper provides a preliminary assessment in regards to the challenges and opportunities of legal frameworks establishment for the deep-sea mining in Indonesia. While Indonesia was statistically at number six of big potential resources in the world with regard to ocean resources [7], ${ }^{4}$ a deep-sea mining was never done before. This paper begins with a brief overview on the shifting tendency from landbased mining to a deep-sea mining and why deep-sea mining should be considered as an important way to overcome resource shortage in land-based mining. Indonesia's deep-sea mining will also be discussed briefly. Furthermore, this paper examines international and regional legal frameworks in deep-sea mining, followed by discussion on national legislation in deep-sea mining. At the end, this paper identifies challenges and opportunities of the legal frameworks establishment for deep-sea mining in Indonesia and proposes solutions to overcome the challenges.

\section{FROM LAND MINING TO DEEP-SEA MINING}

Current development in mineral mining shows the shortage of resources availability over the land. In addition to this, the lack of environment measures in mining activities has raised objections both from local people as well as from non-governmental organization concerned with environment issues. On the other hand, as technology and population grow, the demand of mineral resources also rises. Fewer lands are left to exploit while the demand is growing, and mining companies are shifting toward a new frontier, the smouldering crust of the ocean floor. International community's attention to deep-sea mining activities, in fact, has been around for quite a long time ago. It began to emerge in 1873 when challenger expedition found nodule in sea-bed area and after that it widely spread so that there is possibility for commercial exploitation of such resources.

The advancement in science and technology in mining sector has lead scientists to exploring options for future mineral mining to occur under seas and oceans. In fact, this phenomenon is visible since the earth itself consists of more ocean space than land space. However, similar to what happens in land mining with regard to environmental is sues, global interest in mining ocean floor should carefully considerecosystemas well as marine environment issues.

Indonesia, known as the biggest archipelagic state in the world, in which two third of its territory consists of ocean space, unsurprisingly has potential in mineral mining. In fact, Indonesian mineral sector constitutes potential contributor to national economy. However, such mining

Extraction of aggregates targeted for aggregates, diamonds, tin, magnesium, salt, sulphur, gold and other heavy minerals has generally been conducted in shallow near shore or known as near-shore mining that is less than 50 meters water depth. Whereas dee-sea mining targeted for deeper waters which look set to proceed with phosphate, massive sulphide deposits, manganese nodules and cobalt-rich crust.

However, the $6^{\text {th }}$ rank of Indonesia is for general mining, not specifically for ocean mining. While there is no exact data on ocean mining, Nurkholis et.al stated that among the 60 basins potential of containing oil and gas, 40 basins are offshore basins, 14 basins are on the coasts and only six basins are on the mainland. His research also shows that Indonesia's marine minerals are one of the greatest in the world. activities were still conducted in land. Nevertheless, such land-mining was also still not optimal since only $0.1 \%$ of Indonesian landmass was exploited. In addition to the 'unuse' land areas, there are areas which have not yet been targeted for mineral exploitation, ocean floors. Scientist has been pessimistic on the possibility of minerals mining in the ocean based on geological circumstances. Thus, it is not being overly optimistic to speculate that many more discoveries will occur in the future.

It is argued that such pessimistic argument might be caused by decreasing trend in Indonesian mining industry. While as stated earlier that Indonesia is the number six of big potential resources in the world, ${ }^{5}$ research shows that since 1998 there has been a decrease in exploration and feasibility expenditure [8]. Suryantoro further argued that such decline in mining exploration was triggered by the enactment of various discouraging national regulations [8]. In contrast, Djalal argued that International consensus guarantees the mechanism (international legal framework and institutions) as well as supporting fund (with regard to transfer of technology) for deep-sea mining [9]. Djalal further argues that with magnificent mineral resources lies beneath Indonesian ocean, Indonesia should start to look at such potential [9]. Discussion on international legal framework will take place in due course.

\section{INTERNATIONAL AND REGIONAL LEGAL FRAMEWORK IN OCEAN MINING}

Starting point of International legal framework examining deep-sea mining lies in the LOSC. This Convention put basic arrangement for comprehensive activities conducted over the ocean space. It introduces various maritime zones over which the degree of sovereignty and jurisdiction of coastal states determined accordingly. Such maritime zones imply that the farther the ocean space is from the coast, the less sovereignty and jurisdiction of coastal states will be. The arrangement of such maritime zones also accommodate other states' interests while preserving coastal states' sovereignty and jurisdiction over the ocean space, as well as over the resources therein. The maritime zones further provide ocean space within national jurisdiction, which include internal waters, archipelagic waters (only for an archipelagic state), territorial waters, contiguous zone, economic exclusive zone (EEZ) and the sea floor beneath such maritime zones, known as continental shelf; and ocean space beyond national jurisdiction, which consists of high seas and areas (for the ocean floor beneath the high seas) [10].

Maritime zones provided by the LOSC are measured from the baselines, which is drawn according to state's geographical forms. On the landward side of the baselines lies internal water, over which coastal states have compete sovereignty as its sovereignty on land territory [11]. ${ }^{6}$ This situation applies the same over territorial sea that is an adjacent belt of sea that may extend up to twelve nautical miles from the baselines [12]. ${ }^{7}$ Further is contiguous zone,

This number is for general mineral resources, not specifically ocean mineral resources.

6 This consequently is close internal waters from the rights of passage of foreign vessels as well as exploitation and exploitation of ocean resources from other states

7 However, full sovereignty of coastal states over their territorial seas is not unlimited, but it is limited by the existence of the rights of innocent passage of foreign vessels. 
where coastal states have limited jurisdiction only with regard to sanitary, fiscal and immigration law enforcement. It is then followed by EEZ up to the maximu m of 200 nautical miles from the baselines. Over the EEZ, coastal states only have sovereign rights only and specifically on the exploration on the exploitation of ocean resources [13]. ${ }^{8}$ Beneath such maritime zones lies Continental Shelf (CS) up to 200 nautical miles ${ }^{9}$, over which coastal states have sovereignty and jurisdiction dictated by the regime of the waters above the continental shelf [14]. Article 77 of the LOSC gives coastal states the rights to engage in the exploration and exploitation of the natural non-living resources of the seabed and subsoil within its national juris diction.

Beyond the EEZ are high seas and the area (ocean floor beneath the high seas). As stated previously, these high seas and the area are considered as ocean space beyond national jurisdiction. Within the area, deep-sea minerals such as phosphate, massive sulphide deposits, manganese nodules and cobalt rich crust, as well as polymethallic nodule are found. As stated previously that since the challenger expedition in 1873, international community has identified the possibility of commercial exploitation of ocean minerals resources upon the shortage mineral resources from land. This raises questions as who would own such resources and what legal regimes should be applied over the waters within which such resources lie. The discussion on the commercialisation of nodule exploitation began in 1970s. At that time, it was concluded that there should be an exact regime of sea-bed area. This is because the unrestricted exploitation of nodule would disadvantage land-based exporter state, such as Congo which produces cooper and cobal, as well as Gabon which produces manganese. Thus it was acknowledged that as international law, stood the main benefit of mining that would accrue to a handful of developed state. Another point of view submitted that the commercialisation of sea-bed exploitation would benefit coastal states, since coastal states would give certain areas of sea-bed to another state. As international discussion on the sea-bed mining continues, it proposed at least three choices for the regimes of sea-bed [15]. First option was to consider sea-bed as res nullius, which put sea-bed as a place where no state can own it. The second option was to consider sea-bed as res comunis, that is anyone may exploit sea-bed but no body owns the sea-bed. This option would give benefit to capitalist state. The third option was to consider that sea-bed can be owned by the way of occupation. This way, not only can mining states have sea-bed resources, but they will also be the owners of all ocean floor. Since there was no agreed arrangement reached for the deep-sea mining, in 1967 Dr. Avid Pardo from Malta brought the matter to the United Nation General Assembly who put the discussion to the Committee of the Peaceful Uses of the Sea-Bed and Ocean Floor beyond the Limits of National Jurisdiction. As this turns out, the LOSC provides a common heritage of mankind, that is the exploration and exploitation of which shall be carried out for the benefit of mankind as a whole, for

Within the continental shelf beneath the EEZ, deep-sea minerals, such as phosphate, massive sulphide deposits, manganese nodules and cobalt-rich crust may start to be found although some minerals such as aggregates, diamonds, tin, magnesium, salt, sulphur, gold and other heavy minerals can be found near off-shore in the depth of less than 50 meters.

9 The CS may extend beyond 200 nautical miles, under specific criterion set out in Article 76 of the LOSC. deep-seabed and regulates its governance within Part XI of the LOSC [16]. As for the institution, in order to regulate areas outside national juris diction the conduct of prospecting or exploration, or exploitation of deep-sea bed, an independent and autonomous body, the International Seabed Authority (ISA) was established by the LOSC [17]

In addition, other provisions of LOSC which is relevant to deep-sea mining are Part XII on the Protection and Preservation of the Marine Environment, Part XIII on Marine Scientific Research and Part XIV on Technology Transfer. Furthermore, to accommodate many industrialized states dissatisfied with Part XI of LOSC, an Implementation Agreement relating to Part XI of LOSC was concluded on 28 July 1994 (1994 Agreement). Further guidance on sponsorship and contract engaged in deep-sea mining activities is provided by International Tribunal of the Law of the Sea (ITLOS). Beside those legal provisions, there is also Mining Code, which consists of Annex III of LOSC, which sets up regulatory regime for deep-sea mining in the area, as modified by Part XI of 1994 Implementation Agreement and regulations and procedures adopted by ISA. It follows from the above that there has been international legal framework in place for deep-sea mining in areas beyond national jurisdiction.

As for deep-sea mining in areas under national jurisdiction, under LOSC coastal states can design and adopt their own legislation subject to their obligations under international law. Unfortunately, there are as yet no internationally agreed standard for deep-sea mining in areas under national jurisdiction. LOSC is silent on how coastal states are to regulate deep-sea mining in areas within their national jurisdiction. This consequently results in differences and might be stricter standard of deep-sea mining applied in areas within national juris diction. In designing and adopting their own national laws in deep-sea mining under national jurisdiction, coastal states should consider the Convention on Biological Diversity (CBD) and London Convention on the Prevention of Marine Pollution by Dumping of Wastes and other Matters. In addition to this, other international customary laws also should be considered. There are also no regional rules that have been specifically developed by states in the region who shared ocean space like Southeast Asia States to regulate deep-sea mining within national jurisdiction.

The following part will discuss Indonesian Laws concerning mining in general and examine whether national laws in deep-sea mining have been in place.

\section{INDONESIAN LEGAL FRAMEWORK ON DEEP-SEA MINING}

Indonesian Constitution 1945 (1945 Constitution) provides that the earth, waters and natural resources contain therein should be used for the welfare of Indonesian people [18]. With regard to mining and the use of natural resources, Indonesian laws do not distinguish between lend-based natural resources and ocean based-natural resources. In general, the mining laws in Indonesia can be found in Indonesian Act number 4 Year 2009 on Minerals and Coal (Mining Act 2009). In addition to this, there is also draft on Indonesian Act concerning oil and gas, however this Act has not been in forced yet. This draft is still in discussion from the year 2011 and up to now has not been approved yet. 
Article 1 (1) of Mining Act 2009 defines mining as "part of all of the phases of activities in the fra mework of research, management and exploitation of minerals or coal, which include general investigation, exploration, feasibility study, construction mining, processing and refining, transportation and sales, and post min ing activities [19]." It follows from the above that mining covers range of activities ranging fro $m$ feasibility study to post mining activities. Article 1 (2) further defines minerals as "inorganic compounds formed in nature, which have certain physical and chemical properties as well as a regular crystal arrangement or a comb ination that forms rocks, either in loose or solid form [20]." Whereas minerals mining is defined in Article 1 (4) of Mining Act 2009 as "mining of minerals in the form of ores or rocks, outside geothermal, oil and gas, and groundwater [21]." In specific Article 34 of the Act envisages that minerals mining include: (i) radioactive minerals mining, (ii) metal mineral mining, (iii) non-metallic mineral mining and (iv) rocks mining [22]. This Act is, however, silent on the matter of ocean mining as well as deep-sea mining. Nevertheless, this Act provides the authority of government in mining on ocean areas, both within the distance of 12 nautical miles from coastline [23] and over the areas beyond 12 nautical miles (that is beyond national jurisdiction) [24]. Article 6 (1) (f) and $(\mathrm{g})$ provides that the government has the authority in giving approval for mining activities in ocean areas beyond 12 nautical miles. Article 7 and 8 further envisage that for ocean areas within 12 nautical miles, the authority in giving approval for mining activities is delegated to provincial government and city/ district government. Article 7 (1) (b) (c) and (d) envisage that the authority of provincial government is from 4 nautical miles up to 12 nautical miles from the coastline, while Article 8 (2) (a) and (b) envisage that the authority of city/ district government is up to the maximum of 4 nautical miles. Such arrangement is in contrary to Indonesian Act number 27 Year 2007 on the management of coastal areas and small islands, which gives the authority of city/ district government only one third of provincial government's areas (that is only for a maximum of one third of 12 nautical miles and thus not necessarily 4 nautical miles). However, Indonesian Act on Regional Government ${ }^{10}$ has been revised and eliminated the authority of district/ city government in ocean usage. Accordingly, Indonesian Act number 27 Year 2007 was also revised by Indonesian Act number 1 Year 2014 on the revision of Indonesian Act number 27 Year 2007 on the management of coastal areas and small islands. Mining Act 2009 has also undergone revisions accordingly. Although the revision of Mining Act 2009 is still in progress and has not yet been approved, the revision is in fact included and clearly states the provisions on ocean mining.

The revision of Mining Act 2009, especially in the acknowledgement of ocean mining has raised protests from environment activists since they are worried about the protection of marine ecosystem affected by ocean mining. For the purpose of this paper, although the accommodation of ocean mining on the draft revision of Mining Act 2009

Indonesian Act number 32 Year 2014 on Regional Government amended to Indonesian Act number 23 Year 2014 also amended to Indonesian Act number 9 Year 2015 on the revision of Indonesian Act number 23 Indonesian Act number 32 Year 2004 on Regional Government that has been amended to Indonesian Act number 23 Year 2014, which has also been amended to Indonesian Act number 9 Year 2015 on the revision of Indonesian Act number 23 Year 2014 on Regional Government. can be seen as a good starting point with regard to deep-sea mining, however, there is unclear definition and terminology on ocean mining. Within the academic paper of the draft revision, the terminology of "underwater mining" is used while the draft revision uses the terminology of "under-ocean exploration". This different terminology raises a question as whether underwater mining refers to ocean mining (underocean mining) or might include mining in rivers, such as sand mining? In addition to this, it is argued that the inclusion of ocean mining within the draft revision of Mining Act 2009 needs further study [25].

Apart from the controversy arises from the idea of deepsea mining, in fact, since Indonesia has massive areas of oceans, the minerals contained therein cannot be ignored and should be used for the welfare of Indonesian people as provided by 1945 Indonesian Constitution Article 33 (3). The commercial exploration of Indonesian ocean's mineral will bring economic benefit to the country. Such an opportunity should overweigh the challenges toward ocean mineral exploration and exploitation. It is submitted that the challenges in exploring and exploiting deep-sea mining include the lack of encouraging national legal framework, financial arrangement of such activities as well as institutional mechanism. While international legal framework on deep-sea mining has been in place since the adoption of LOSC 1982 and Implementation Agreement 1994, unfortunately no guidance is provided for states, especially coastal states on how to nationally regulate their exploration and exploitation mechanism of deep-sea mining. However, this should not prevent coastal states in adopting national laws in deep-sea mining since it is clearly provided in LOSC that such national laws should be made in accordance with existing international law and customary international laws as well as the principles of international laws. This is because minerals contained within the ocean are considered as common heritage of mankind.

Although many things should be considered by states in adopting national laws in sea-bed mining, both within their national jurisdiction as well as beyond their national jurisdictions, some states have already had legal frame work on the matter in place. These states include France, Germany, Greece, Italy, the Netherland, Portugal, Spain and the UK. Of those states, only Germany and the UK have adopted national legislation on the deep-sea mining on the Areas. In addition, Belgium and Czech Republic also have specific legislation on deep-sea mining on the Areas. Canada, China and Papua New Guinea do not have legislation on deep-sea mining on the areas but china has already put it as its important agenda. Fiji and Japan have also adopted legislation on ocean mining [26]. The Table 1 shows which states have already adopted legislation on deepsea mining within their national jurisdiction and bey ond their national jurisdiction and shows the current position of Indonesian legislation: 
table I. National Legislation on Deep-Sea Mining [26]

\begin{tabular}{|c|c|c|c|c|c|}
\hline & \multirow{2}{*}{$\begin{array}{c}\text { Legislation } \\
\text { on deep-sea } \\
\text { mining in the } \\
\text { Area }\end{array}$} & \multicolumn{5}{|c|}{$\begin{array}{c}\text { Legislation on deep-sea mining in areas under national } \\
\text { juristiction }\end{array}$} \\
\cline { 4 - 7 } & $\begin{array}{c}\text { Specific } \\
\text { deep-sea mining }\end{array}$ & $\begin{array}{c}\text { Legislation on } \\
\text { land-based } \\
\text { mining applies } \\
\text { by implication }\end{array}$ & $\begin{array}{c}\text { Spectic } \\
\text { references in } \\
\text { legislation on } \\
\text { land-based } \\
\text { mining }\end{array}$ & $\begin{array}{c}\text { Deep-sea mining } \\
\text { addressed in } \\
\text { other legislation }\end{array}$ \\
\hline Canada & - & - & - & - & - \\
\hline China & - & - & - & $\checkmark$ & - \\
\hline Fiji & $\checkmark$ & - & $\checkmark$ & - & - \\
\hline French & - & - & - & $\checkmark$ & - \\
\hline Germany & $\checkmark$ & - & NA & NA & NA \\
\hline Greenland & - & - & $\checkmark$ & - & - \\
\hline Italy & - & - & - & $\checkmark$ & - \\
\hline Japan & $\checkmark$ & - & - & $\checkmark$ & - \\
\hline Netherlands & - & - & - & $\checkmark$ & - \\
\hline PNG & - & - & $\checkmark$ & - & - \\
\hline Portugal & - & - & $\checkmark$ & - & - \\
\hline UK & $\checkmark$ & - & - & - & $\checkmark$ \\
\hline USA & $\checkmark$ & $\checkmark$ & - & - & - \\
\hline Indonesia & - & - & - & $\checkmark$ & - \\
\hline
\end{tabular}

\section{CONCLUSION}

As the biggest Archipelagic State in the world, two third of Indonesian territory are covered by ocean. This geographical condition of Indonesia brings many economic benefits to Indonesia and one of them is the riches of various ocean minerals. While Indonesia is known as a state that consistently considers crucial role of its ocean, unfortunately, the deep-sea mining activities have never been on its important agenda.

The lack of encouraging legislation in mining has prevented Indonesia too look further on the possibility to explore and exploit deep-sea mining both within and beyond its national jurisdiction. While there is draft revision on Mining Act which specifically provides for deep-sea mining, yet such inclusion raises many objections as to fear of damaging marine environment. In addition to these, financial arrangement as well as institutional arrangement add more challenges to deep-sea mining activities in Indonesia.

However, it is submitted that Indonesia should start to look at the possibility of adopting national legislation for deep-sea mining in both areas within and beyond national jurisdiction. Although international legal framework provides no guidance on the adoption of national legislation on deep-sea mining, such adoption can be done by making it in accordance with principles of common heritage of mankind provided by LOSC and customary international laws as well as principles of international laws.

\section{ACKNOWLEDGMENT}

This research was supported by Law Faculty of Brawijaya University. Thank you to my colleagues at Law Faculty who provided insight and expertise that greatly assisted the research although they may not agree with all of the interpretations of this paper.

\section{REFERENCES}

[1] See generally MPA, Marine Aggregate Teminology: A Glossary, 2014

[2] Puspitawati, Dhiana, "Indonesian Salvage Law Within the Framework of Contemporary Maritime Law", Brawijaya Law Journal v. 2 n. 2, 2015

[3] Puspitawati, Dhiana, "Book Review on Indonesia Beyond the Waters' Edge: Managing an Archipelagic State, Singapore Journal of Tropical Geography Vol. 32 No. 1, 2011.

[4] 1833 UNTS 3

[5] See generaly Final Report Under FWC MAR E/2012/06 - SC E $1 / 2013 / 04$, "Study to Investigate the State of Knowledge of Deep-Sea Mining", 2014

[6] Baker, Alen, “Offshore Mining Industries”, United Nations 2016

[7] Dahlius, Arif Zardi, "Potensi dan Tantangan Pertambangan di Indonesia" Assosiasi Pertambangan Indonesia, 28 May 2014 availabel online at www.ima-api.com; See also Nurkholis et.al, "The Economic of Marine Sector in Indonesia", Aquat ic Procedia 7 (2016) 181, 186

[8] Suryantoro, S and Manaf, MH, "The Indonesian Energy and Mineral Resources Development and its Environmental Management to Support Sustainable National Economic Development", Paper presented in the OECD Conference in Foreign Direct Investment and Environment in Mining Sector, Paris, 7-8 February 2002.

[9] __ Pasal Mengerikan Tambang Bawah Laut, kantor berita Antara, available on-line at http://www.grasnews.com/berita accessed on 13 June 2018

[10] See Part II, V, VI and VII of the LOSC

[11] Article 8 of LOSC

[12] Article 3 and 4 of LOSC

[13] See generally Part V of LOSC

[14] See generally Part VI of LOSC

[15] See generally, Shaw, Malcol N, Introduction to International Law, Cambrige University Press, 1999

[16] See generally Part XI of LOSC and 1994 Agreement relating to the Implementation of Part XI of LOSC

[17] See also Tanielu, Tearinaki. "Establishment of a National Regulat ory Framework for the Exploration and Exploitation of Deep Sea Minerals: A Case Study for Kiribati", Report on United Nation_Nippon Foundation of Japan Fellowship Programme, 2013

[18] Article 33 (3) of 1945 Indonesian Constitution

[19] Articel 1 (1) of Mining Act 2009

[20] Article 1 (2) of Mining Act 2009

[21] Article 1 (4) of Mining Act 2009

[22] Article 34 of Mining Act 2009

[23] Article 7 and 8 of Mining Act 2009

[24] Article 6 of Mining Act 2009

[25] See generally "Revisi UU Minerba Potensial Rugikan Negara", grasnew, 25 March 2016 available on-line at www.grasnews.com accessed on 14 June 2018; Muhammad, Chalid, "Lima Alasan Menolak Draft Revisi UU Minerba Versi USDM", available on-line at www.jatam.org accessed on 13 June 2018; Leonard, Lucky, "Inilah Poin-Poin Baru dalam Revisi UU Minerba" available on-line at www.bisnis.com; Widianto, Arif, "Aturan Baru Pertambangan Minerba 2017, 13 Januari 2017 available on-line at https://bolasalju.com accessed on 12 June 2018; "Pasal Mengerikan Tambang Bawah Laut", grasnews 07 April 2016 available on-line at https://grasnews.com accessed on 14 June 2018.

[26] Final Report under FWC MAR E/2012/06 - SC E1/2013/04 Study to Investigate the state of knowledge of deep sea mining 